Teliya, Veronika. "Nominatsiya (Nomination)". Entsiklopedicheskiy lingvisticheskiy slovar (Encyclopaedic Linguistic Dictionary). Moscow: Bolshaya rossiyskaya entsiklopediya, 1990. Print.

\title{
List of Sources
}

Dovlatov, Sergey. Sobranie sochineniy v 4-h tomah (Collected works in 4 volumes). SPb.: Azbuka, AzbukaAttikus, 2011. Print.

Надійшла до редакції 24 березня 2018 року.

\section{METONYMY AS SEMANTIC MECHANISM OF CREATION LANGUAGE GAME IN DOVLATOV'S CREATIVITY \\ Olga Pushkar}

Slavic Languages Department, H. S. Skovoroda Kharkiv National Pedagogical University, Kharkiv, Ukraine

Abstract

Background: Language game has become the subject of close attention of philologists in recent years. Functioning language game in the works of art is still one of the main problems of modern linguistics. Thus, the study of language game as a characteristic feature of the writer's individual style is perspective and actual direction in linguistics.

Purpose: The purpose of the analysis is to determine the specific features of S. Dovlatov's creative works from the point of view of the functioning of one of the dominant semantic mechanisms of language game metonymy, and figure out the evolution of using the metonymy throughout S. Dovlatov's literary works.

Results: The conducted research allows us to find out typical features due to functioning metonymy, as a semantic mechanism for creating language game, in S. Dovlatov's early and mature works of art. The early period of S. Dovlatov's creative work is characterized by the predominant use of partitive and attributive metonymy types for creation a comic effect. Local metonymy "the container - its contents" model is a widespread local metonymy model for both periods: the early and the mature ones of the writer's creativity. The causal type of metonymic transferences greatly prevails over other types of metonymy in the mature literary works of S. Dovlatov's.Creation of characters' nicknames with causal metonymy is considered to be the characteristic feature of S. Dovlatov's individual style. Many headlines of S. Dovlatov's mature stories are based on causal or local metonymy types.

Discussion: Having analysed S. Dovlatov's individual style in respect of the aspect of language game we have settled that such type of semantic language game as a metonymy is actively used by S. Dovlatov to construct statements with language game in the early and mature periods of the writer's creativity. The prospect of the research implies the study of other typical semantic and syntactic mechanisms of creation language game in S. Dovlatov's early and mature works of art.

Key words: language game, semantic mechanism, metonymy, comic effect, irony, individual style.

Vitae

Olga Pushkar is a post-graduate student of Slavic Languages Department of H. S. Skovoroda Kharkiv National Pedagogical University (spec. 10.02.02. - the Russian language). Her areas of research interests comprise text stylistics and phenomenon of language game

Correspondence: ollgizza@gmail.com

УДК $811.161 .2 ' 42$

Анастасія Тепшич

\section{РОЛЬ МОВНОЇ ГРИ \\ В РЕАЛІЗАЦІЇ ФЕНОМЕНОЛОГІЧНИХ ЕКСПЕРИМЕНТІВ ТАРАСА ПРОХАСЬКА}

У статті доводиться, що вербалізачія споглядальної життєвої філософії персонажів збірки «Лексикон таємних знань» Т. Прохаська потребує спечіальної мови. Автор розглядає засоби та прийоми мовної гри, які виявляються переважно на синтаксичному рівні та полягають в ускладненні структури речення (однорідні, вставні та вставлені конструкиії, повтори і под.).

Ключові слова: ідіостиль, мовна гра, прийоми мовної гри, синтаксична організація тексту, феноменологія, постмодернізм.

Прозова збірка Тараса Прохаська «Лексикон таємних знань» містить твори, написані письменником на початку кар'єри, проте дослідники (Izdryk “Taras Prokhasko: Neirobiolohiia landshaftu“, Holoborodko) вказують на особливу художню цінність більшості ранніх текстів автора, що визначили естетичні, гносеологічні та онтологічні орієнтири, а як наслідок - і стилістичні особливості ідіостилю письменника.

Юрій Іздрик у передмові до збірки звертає увагу на «позірну сповільненість» текстів Т. Прохаська та радить читачам читати прозу «якомога повільніше, найкраще - у тому темпі й тому ритмі, в якому вона була

(C) Тепшич А. I., 2018 
написана» (Izdryk "Pro...za...pro” 10-11). Лідія Стефановська в післямові до того ж видання зазначає, що «сприймати оповідання Прохаська досить складно» і пов'язує ці складнощі із особливостями авторської техніки письма (Stefanovska 178-179). Ярослав Голобородько дає таку характеристику специфічної техніки Прохаська, яка покликана, на думку критика, наочно продемонструвати семантичні та формальні пріоритети автора, а саме: «вдивитися, вгледітися, вслухатися, вчутися, вдуматися в навколишній і внутрішній світ, в кожну його деталь, риску, рисочку, в усі мислимі і немислимі дрібниці, яких за його (Прохаськовою) почуттєвою і сенсорною логікою, не існує і не може існувати» (Holoborodko 48). Тамара Гундорова пише про те, що «у повістях Тараса Прохаська... чи не вперше оприявлюється нова манера письма 3 вираженою риторичною побудовою», для якої характерна «своєрідна морфологічність тексту», що «означає матеріалізацію формальних мікроструктур, які повторюються і стають базовими в процесі образотворення та при побудові наративної структури твору» (Hundorova 97).

Як бачимо, усі дослідники творчості Тараса Прохаська сходяться на тому, що ідіостиль письменника вирізняється ускладненістю організації художніх текстів. Оскільки творчість письменника $\epsilon$ «післякарнавальною» версією постмодернізму, то мовна гра в нього позбавлена «грайливості», саме 3 іiі допомогою автор творить рекомбінації та складає нові структури.

На жаль, попри велику зацікавленість стилем Тараса Прохаська з боку літературознавців, особливості художнього мовлення письменника не привертали увагу лінгвістів. Представлена розвідка є частиною праці «Мовна гра як домінанта постмодерного дискурсу (на матеріалі прозових творів представників станіславського феномена)», де впреше на всіх рівнях мовної організації тексту було досліджено прийоми та функції мовної гри письменника.

У статті спробуємо простежити, які прийоми мовної гри використовує Тарас Прохасько для створення власної неповторної техніки письма та яке стилістичне та образотворче навантаження вони несуть.

У колі філологів стало звичкою називати Т. Прохаська «наскрізь рослинним чоловіком», і це пов’язано не стільки $з$ тим, що письменник за фахом є ботаніком, а перш за все з тим, що уся його творчість просякнена рослинними соками. На лексичному рівні організації його творів це виявляється в постійній присутності назв рослин та їх частин. Це додає текстам своєрідного шарму: «тисячі різнокольорових $i$ найвишуканіших за формою пилкових зерен, спор, обірваних тичинок, кісточок роздушених ягід $і$ уламків потовчених сухих плодів» (Prokhasko 75). Герої Т. Прохаська, ким би вони не працювали, чим би не займалися, обов'язково розуміються на рослинах, збирають гербарії чи доглядають за вазонками. Для них рослини - це досвід: «білі стовбури буків, смердюча рідина на мокрому каштані, гладка і слизька кора перемоченого горіха, ліс вічної осені, археологічні зрізи падолистів, вибілене снігом і висушене, аж бляшане листя останнього шиару, анемони, гепатіки мускарії, кальти, пульсатілі, фіалки, сині яри, жовті тіні, розмочування папоротей, найбільше всього можна навчитися у рослин (небозпосередній досвід)» (Prokhasko 81-82). А оскільки «не буває досвіду зайвого», такі розлогі списки не є надмірними, адже кожний їхній елемент містить в собі глибину чийогось досвіду. Цікаво, що автор надає перевагу латинським назвам рослин, а не їхнім народним відповідникам. Якщо використання латинських назв у творах Ю. Іздрика є показово ігровим, штучним, то для Т. Прохаська назви рослин - «субстанція для властивостей, в тім числі і вербальних, паралельна лінгвістика, нелатина, еквізетум, сиіля, юніперус, крокус, цикламен, иіпріпедіум, фрітілярія, арніка монтана, скорзонеля, нечуйвітер (омела)» (Prokhasko 84). В одному з інтерв'ю (для live.karabas.com) письменник зізнається, що в ранній період творчості йому «хотілося, щоб проза звучала як музика». Перелік латинських назв рослин саме так і звучить, слова підібрані таким способом, що свторюють ритмічний та римований малюнок (юніперус крокус, еквізетум - ціпріпедіум). Але, на відміну від Ю. Андруховича, в якого проза показово набуває рими заради створення карнавального настрою, у Т. Прохаська мовній грі «належить другорядна роль, вона виникає наче випадково в процесі писання» (Stefanovska 180).

Фонетичні (6\%) та лекчисні (13\%) мовні ігри в текстах письменника не є визначальними, автор не намагається створити їх штучно, вони виникають в результаті властивостей самої мови, адже сказати інакше, підібрати інші слова часом просто неможливо: «Осінь - привид. Або: осінь - привід. Або: осінь - це провід» (Prokhasko 16), «назвемо неназване, виберемо невибране, уможливимо неможливе» (Prokhasko 25).

Натомість особливу увагу автор приділяе синтаксичній організації своїх текстів (мовна гра на цьому рівні складає $62 \%$, решту $19 \%$ складає мовна гра з пунктуацією та розташуванням тексту на сторінці). У вже згаданому інтерв'ю письменник говорить про те, що застосовує у своєму писанні дві взаємопротилежні стратегії: одна - ритмізація прози для легшого читання, інша - «коли література - це тренажерний зал. Коли речення навмисне побудовані так, щоб читач долав їхній спротив. Як тягати залізо, так і тут». Саме ця друга стратегія є визначальною та створює індивідуальний, легковпізнаваний стиль Т. Прохаська, який Т. Гундорова не безпідставно визначила як «риторичний апокаліпсис» (Hundorova 97-104). Дослідниця зазначає: «Морфологічне Прохаськове письмо відтворює процес розпаду пам'яті, свідомости на дрібні мікроструктури: відчуття, моменти часу, спалахи пам'яті...», таким чином «створюється незвична комбінаторна феноменологія, щось схоже на медитативні пасьянси із залишків речей і думок» (Hundorova 100).

Головним завдянням феноменології як філософського напряму є вивчення структур свідомості та явищ, які в ній відбуваються, при чому цей розгляд має здійснюватися від першої особи. У своїх художніх текстах Т. Прохасько, очевидно, натхненний ідеями Е. Гуссерля, намагається об'єктивно описати суб'єктивне, тобто процеси мислення, судження, сприйняття. Це призводить до вибору характерної для письменника наративної 
стратегії: хоча оповідь ведеться від третьої особи, проте зазвичай має форму потоку свідомості, із незвичними асоціаціями, неймовірними деталями у відтворенні почуттів та емоцій, тенденцією до катологізації. Для створення художнього ефекту потоку свідомості Т. Прохасько послуговується матеріалом, який щедро надає синтаксис. Експерименти із структурою речення - невичерпне джерело для вирішення багатьох художніх завдань. Наприклад, щоб відтворити особливості сприйняття дійсності героя автор вдається до ускладнення речення однорідними членами, різними типами синтаксичного зв'язку (13 речень поєднані у складне за допомогою різних типів синтаксичного зв'язку) та об'ємною вставленою конструкцією: «Звуки ж відстають або випереджають те, від чого вони мали б залежати, тому те, від чого мали б залежати звуки, є або сповільнено-розтягненим, або пришвидшено-стислим: вдарився ще у парку головою об галузку, хоч ніякої галузки і не було видно, але все ж він нагинався, то як міг зачепитися, $і$ де міг подітися пакунок з тютюнами, якщо його не підібрав шахіст, чи там, де пили пиво, і сонце настільки спотворило бачення через звичайне шкло, щьо знадвору всередину виглядало як тераріум з іншими істотами і внутрішнім підсвітленням (а зсередини - ніби сидиш у пивниці під вікном із сонцем на заході, а людей бачиш лиш тих, щзо найближчі, $i$ знизу догори, чи у трамваї, щчо їзив у неділю від иявинтаря до цъвинтаря, це попри будинок Памви, але з таким загущеним запахом хризантем, щз вже би нудилло, якби якийсь інший запах, а не хризантем)» (Prokhasko 123). Такі завеликі та затяжкі для нормального сприйняття речення могли б здатися несмаком, стилістичною вадою, якби не несли особливого навантаження - автора не стільки хвилює, як сприйматиметься його твір, скільки важливим є відтворення усіх, навіть найдрібніших відчуттів (зорових, слухових, викликаних запахами) та асоціацій головного персонажа. Не дарма Ю. Іздрик назвав письменника колекціонером досвідів. Персонажі Т. Прохаська особливі, здається, що для них мислення, враження від дійсності важливіші за саму дійсність. Памва - головний герой твору «Від чуття при сутності» - хоче написати музичну п’єсу. Він має безліч задумів, у тексті наведених у вигляді багатокомпонентної ампліфікації: «...буде грати однією рукою, або зв'яже кисті, або буде розтягати пальиі однієї руки просто на клавіатуру другою, або по-справжньому вп'ється впродовж виконання, або поскладає на клавіатуру квіти, або ударятиме по клавішах кулаком, чи чолом, чи буде перекочуватися головою, або поріже пальці $і$ буде кров, або забинтує порізані пучки, або вдягне рукавиці, або наповнить нутрощуі фісгармонії горіхами, або засне, або ляже на підлозі...» (Prokhasko 137-138), перелік продовжується, але задуми героя не зреалізуються, бо дійсність все спотворить, вона не здатна передати задум цілісно, тому останній елемент ампліфікації - «або зовсім нічого не робити, лиш пробути» (Prokhasko 138).

Прийоми перерахування в прозі письменника можуть створювати протилежні ефекти - прискорення та сповільнення оповіді. Прискорення досягається завдяки конденсації подій в одній низці перерахувань. Наприклад, Северин редукує «події власного життя... до кількох визначальних фрагментів»: «до жінки, якою є всі інші жінки по-різному, до води, без якої неусвідомлено нудишся, до вітру з вигаданим запахом, якого не віднайдеш, до болю, після якого живеш без жодного страху...» (Prokhasko 86). Звичайно, не варто шукати в переліках Т. Прохаська певної сюжетності, адже, за філософією автора, важливі не події, а емоції та досвід, які вони залишають. Так, життя персонажа зведено до переліку ключових досвідів, який дає читачу більше інформації про героя, ніж детально виписаний життєпис. До сповільнення оповіді письменник вдається знатно частіше, таких прикладів у його творах безліч. Саме завдяки ним складається загальне враження медитативності, уповільнення текстів - характерної особливості стилю Т. Прохаська. До детального переліку мікроподій одним реченням вдається автор для опису періоду перебування персонажів в пансіонаті пані Вікі: «Були страшенні морози, ми їздили на санях, сани ночували в кімнаті, стіни довго розмерзалися, Анна їла сніг, ми опалювалися на горі, гріли одяг біля печі перед тим, як вбратися, всі говорили тільки про мороз, Анна не дозволяла собі курити, дзеркало висіло якось високо, і вона, розробляючи серію актів для нового альбома фотографій, мусила ставати на крісло, $і$ я дивився на ї дивовижні пози, на грубезні капчурі на ногах, напалюючи піч до світіння кахлів вилежалими буковими дровами, ми мали з собою багато трейпфрутів, робили зі знятої шкурки попільнички для ліжка, пообвітрювали губи і поморозили руки, шклянку із спиртним треба було перехиляти далі за губами, бо вони пекли від спирту, а в руки Анні я втирав крем, хоч ми мусили робити на ліжку шатро з ковдри, нагріваючи собою хоч трошки повітря, запах крему завжди перебивався запахом Анни і моїм» (Prokhasko 27-28).

Персонажі Прохаська шукають досвіду в спогляданні та зосередженні на кожній деталі, кожній, навіть незначній події, фіксуючи всі етапи мікроподій, демонструючи максимальну напругу власної уваги. Характерно, що персонажі не прагнуть здобути новий досвід, а намагаються систематизувати, каталогізувати вже набутий. Саме тому проза письменника безсюжетна, натомість переповнена детальними переліками. Так, розділ «Курити» дослідження Маркуса Млинарського «розтинався кількома десятками площин на кількасот підрозділів, таких як курити люльку, курити тонкі сигарети, курити тютюн, загорнений в газету, - це за одною площиною розтину, а ще за іншими - курити в горах, курити в приміщенні, курити на самоті, курити ситрету за ситаретою...» (Prokhasko 57). Така надмірна деталізація найпростіших процесів призводить до втрати зв'язку із реальністю, до певного типу божевілля, тому в продовженні цитати відсутні розділові знаки, роль яких - розмежовувати думки, виділяти головне, адже персонаж, заглиблений у самоспоглядання, вже не спроможний на сигментацію мисленнєвого потоку: «курити в ліжку під ранок ї̈ ситарети витонченого смаку що майже невідчутне запаху обдимленості попільничка на грудях іноді попіл падає на простирадло перетворюється на сіру пляму від засильного струшування триває довше ніж звичайно лиш тримання ситарети стримує від сну однак те що говориться є вже фактично маренням свідомість погоджується 3 виміром заданим напрямом координатних шкал положення сигарет» (Prokhasko 57-58). 
Зосередженість на деталях закономірно призводить до домінування в текстах описів. Описів завнішності персонажів у Т. Прохаська майже немає, зазвичай автор обмежується описом їхнього одягу, однак описи інтер'єрів та пейзажів виписані до подробиць. Але письменник не акцентує на тому, як виглядають конкретні предмети, його деталізація полягає в старанному занотовуванні та перерахуванні усіх предметів, що заповнюють простір: «Світилися лампи різної сили, закріплені в різних місцях. Лампи були $i$ спеціальні, $i$ звичайні жарівки, настільні $i$ прожектори, $i$ кишенькові ліхтарики... Крім того, оператор маніпулював складною системою скерованих на сцену світел. Різні рівні. Підмостки, гойдалки, куби, лавки, свічки i підсвічники. Текла вода. 3 кранів, $з$ пробитих куль, з перехилених посудин» (Prokhasko 62). Каталогізація - не просто стилістичний прийом, у Т. Прохаська це своєрідна філософія. Ще одна особливість описів письменника - іхня кіноматографічність. Незважаючи на те, що персонажі уважно сприймають дійсність, їхнє мислення та сприйняття оточуючого є фрагментарним. Звідси - своєрідна монтажність в описах: чергуються плани, виокремлюються деталі, просторові ракурси і под. Дійсність постає як зміна кадрів: «Були висячі мости, стежки, альтанки, смітники, хатини, городи і квітники, копанки, вулики, дорога, боки завалених мостів і покручені уламки залізничих рейок, зграї птахів, звірі пили воду, мурашники, осині гнізда, човни на напнутих ланцңюгах» (Prokhasko 94-95), «до озера збігалися дахи, ипилі, мости, кладки, мансарди, веранди, галереї, ганки, балкони, комини, дерева, виноградники, скелі, зруби, річні острівки, бастіони і форти цүитаделі, сади, городи, ожинові нетрі, сходи, каплиці, скелі, пустища і смітники, колії...» (Prokhasko 92).

Авторська зосередженість на найдрібніших нюансах нерідко призводить до семантичної надлишковості. Тексти Т. Прохаська рясніють різноманітними повторами. У новелі «Довкола озера» кілька абзаців закінчуються вставленими конструкціями, наприклад, «(короткий час извітіння ірисів)», а наступний абзац продовжує цю думку: «короткий час цъвітіння ірисів припадає на останні дні у місті перед літом» (Prokhasko 83). Часто автор вдається до повторів суб'єкта в реченні: «Вона втрачала найзначнішу частину свідомості, коли була закатарена і нюх не функціонував. Вона переживала светри, знайдені у шафах, як флірти, випадкові і швидкоплинні контакти. Часом вона розкурювала люльку...» (Prokhasko 50) або кожне речення другої частини твору «Від чуття при сутності» починається іменем головного персонажа (Памва), яке виконує синтаксичну функцію підмета. Досить частотними є і синонімічні повтори, що створюють враження непотрібної надмірності: «клей прилипав до всього, чого лише торкався Северин, і плетиво множилося, створюючи павутину, густі фарби, хитромудру антену, систему смоляних судин на зрізі сосни, плутанину химерних вузлів чи схему залізничого сполучення довкола великого європейського міста, сфокусовану тінь тонкого крила жука або лабіринти дактилоскопї̈» (Prokhasko 74-75).

Повтори в текстах Т. Прохаська мають ускладнену структуру, наприклад, основна думка висловленого зберігається, проте суб'єкт та об'єкт дії міняються місцями: «Але тепер я маю роман з вулицею. Або: вулиця фліртує зі мною» (Prokhasko 18), або в частині, що повторюється, висловлена думка деталізується, уточнюється: «Існє мислення, неможливе без запахів. Або: існує мислення, чиїми категоріями є запахи. Або $\epsilon$ такий тип мислення, де думка - запах, заnаx - думка» (Prokhasko 16), за допомогою заміни одного компонента на антонімічний висловлення набуває нового значення: «Ми опустилися у відвертості аж до дитинства. Або: ми піднялися у своїй відвертості аж до дитинства» (Prokhasko 17).

Один із персонажів Т. Прохаська Маркус Млинарський демонструє споглядальну увагу до всього та розмірковує над створенням «якогось тексту шляхом тривалих генетичних рекомбінацій-кроків». Згаданий в новелі прийом рекомбінацій є стильовою домінантою прози Т. Прохаська. Так само, як під час рекомбінацій ланцюжок ДНК розривається, а його фрагменти об’єднуються в іншому порядку, уривки текстів письменника, основні лейтмотиви його творів сполучаються щоразу в іншому порядку, уточнюючи, поглиблюючи думку, розгортаючи нові низки асоціацій, породжуючи нові смисли та сюжети.

Загострення авторського погляду на деталях, спроба представити дійсність не за допомогою опису самої реальності, а за допомогою передачі вражень від неї потребують специфічного синтаксису. Мовна гра на цьому рівні є визначальною для творів Т. Прохаська. Різноманітні повтори, хіазми, ампліфікації та інші ускладнення структури речення покликані донести до читача естетичні засади феноменологічної творчості письменника. Така синтаксична організація на рівні цілого тексту ускладнює сприйняття, змушує читача читати повільно, щоразу повертатися до початку речення чи абзацу, примушує відчути твір, вхопити «відчуття присутності», за допомогою «чуття» наблизитися до «сутності». Синтаксичній мовній грі Т. Прохасько додає виразності використанням різноманітних графічних прийомів, що послугують предметом наших подальших студій.

\section{References}

Beregovskaia, Eda. Ocherky po ekspressyvnomu sintaksisu (Essays about expressive syntax). Moscow: Rokhos, 2004. Print.

Holoborodko, Yaroslav. Artegraund. Ukrainskyi literaturnyi isteblishment (Underground. Ukrainian literary establishment). Kyiv: Fakt, 2006. Print.

Hundorova, Tamara. Pisliachornobylska biblioteka. Ukrainskyi literaturnyi posmodern (Post-Chornobyl Library: Ukrainian Literary Postmodernism). Kyiv: «Chasopys «Krytyka», 2005. Print.

Izdryk, Yurii. “...Pro...za...pro (Pro...se...pro)” Leksykon taiemnykh znan (Lexicon of secret knowledge) by Prokhasko Taras. Lwiw: Kalvariia, 2006. Print. 
Izdryk, Yurii. "Taras Prokhasko: Neirobiolohiia landshaftu (Taras Prokhasko: Neurobiology of the landscape)". Istoriia literatury v avtorakh i tekstakh (The history of literature: authors and texts) (2014). Web. 1 Oct. 2017.

Prokhasko, Taras. Leksykon taiemnykh znan (Lexicon of secret knowledge). Lwiw: Kalvariia, 2006. Print.

Rossman, Vadim. "Tekhniki punktuatsii: znak prepinanyia kak filosofskii metod (Punctuation techniques: punctuation as a philosophical method)". Voprosy filosofii (Issues of philosophy) 4 (2003): 68-76. Print.

Stefanovska, Lidiia. "Dovhe pidvodne plavannia (Long scuba diving)". Leksykon taiemnykh znan (Lexicon of secret knowledge) by Prokhasko Taras. Lwiw: Kalvariia, 2006. Print.

Tepshych, Anastasiia Movna hra yak dominanta postmodernoho dyskursu (na materiali prozovykh tvoriv predstavnykiv stanislavskoho fenomena) (The language game as the dominant of postmodern discourse (based on the prose works of representatives of the Stanislav phenomenon). Belgrade; Vinnytsia: Nilan-LTD, 2017. Print.

Yermolenko, Svitlana. Syntaksys $i$ stylistychna semantyka (Syntax and semantics of stylistic). Kyiv: Naukova dumka, 1982. Print.

Надійшла до редакції 24 березня 2018 року.

\section{THE ROLE OF LANGUAGE-GAME IN REALIZATION OF PHENOMENOLOGICAL EXPERIMENTS OF TARAS PROKHASKO}

Anastasiia Tepshich

Department of General and Applied Linguistics and Slavonic Philology, Donetsk National University named after Vasyl Stus, Vinnytsia, Ukraine;

Department of Slavonic Philology, University of Belgrade Belgrade, Republic of Serbia

\section{Abstract}

Background: Insufficient study of the language-game as an element of the language of the artistic literary work requires the description of its manifestations in this communicative sphere. The language-game in postmodern texts by Taras Prokhasko is caused by the author's ideological, thematic and artistic aesthetic directions. The relevance of the study is caused by the need to study the function of the language game which is used to reflect the author's phenomenological worldview and aesthetic influence on the reader.

Purpose: The goal is to research the methods of the language game used by Taras Prohasko in order to create his own unique technique of writing and what kind of stylistic and pictorial work they bear.

Results: Phenomenological experiments by T. Prokhasko are primarily related with the attempts of the characters in his texts to objectively describe and learn what is usually considered to be subjective - consciousness, feeling, perception. Verbalization of such a life philosophy has affected the specifics of the language in his works. The language-game in the texts of the collection "The Lexicon of Secret Knowledge" is used on the phonetic, lexical and syntactic levels. Language-game on the syntactic level is crucial for writer's idiostyle, because it is created by using stream of consciousness technique, cataloging, cinematography, recombination, detailing, etc. Language-game on the syntactic level is used to put emphasis on the details of the author's point of view, in an attempt to present reality not by the description of the reality, but by passing impressions of it. Because of that the syntax of Taras Prokhasko is complex and consists of repetitions, chiasmuses, amplifications, and other types of complex sentence structure. All of this is in order to convey the aesthetic principles of phenomenology to the reader.

Discussion: The problem of linguistic study of the works of Ukrainian postmodernists requires an integrated, interdisciplinary approach to the phenomenon of language-game.

Keywords: idiostyle, language-game, receptions of language-game, syntactic organization of text, phenomenology, postmodernism.

\section{Vitae}

Anastasiia Tepshich is PhD, Junior Research Fellow at Department of General and Applied Linguistics and Slavonic Philology at Donetsk National University named after Vasyl Stus and Lector of Department of Slavonic Philology, University of Belgrade. Her areas of research interests include functional linguistics, cognitive linguistics and text linguistics.

Correspondence: bilozubnastja86@gmail.com 